\title{
Immunomodulatory effects of Radix isatidis polysaccharides in vitro and in vivo
}

\author{
WEI TAO, TING FU, ZHUO-JING HE, HAN-PENG ZHOU and YAN HONG \\ School of Bioengineering, Hangzhou Medical College, Hangzhou, Zhejiang 310013, P.R. China
}

Received May 13, 2021; Accepted August 18, 2021

DOI: $10.3892 / \mathrm{etm} .2021 .10841$

\begin{abstract}
Radix isatidis (R. isatidis) is a commonly used traditional Chinese herbal medicine, which has been used for thousands of years in China and is believed to have the pharmacological properties of heat-clearing and detoxification. Heat-clearing and detoxification are theories of traditional Chinese medicine meaning that $R$. isatidis could treat febrile disease by clearing heat and reducing swelling. Polysaccharides isolated from $R$. isatidis by water extraction and alcohol precipitation have exhibited numerous biological activities, including antiviral and immunomodulatory effects. The present study was performed to investigate the immunomodulatory effects of water-soluble $R$. isatidis polysaccharides (RIPs) on RAW264.7 macrophages and murine splenocytes, and attempt to preliminarily identify the mechanism of immunomodulation. In vitro, RIPs had a low cytotoxicity, as shown by CellTiter $96^{\circledR} \mathrm{AQ}_{\text {ueous }}$ One Solution Cell Proliferation Assay. RAW264.7 cells treated with different concentrations of RIP displayed different morphological changes, from a round shape and aggregation to polygonal shape and dispersion in a dose-dependent manner. In the $5 \mathrm{mg} / \mathrm{ml} \mathrm{RIP-treated} \mathrm{group,} \mathrm{the} \mathrm{changes} \mathrm{of} \mathrm{morphology}$ were as same as the lipopolysaccharide-treated group. RIP also significantly enhanced the release of nitric oxide as shown by Griess method, and the secretion of TNF- $\alpha$ and IL- 6 in RAW264.7 cells was confirmed by ELISA assay. Western blotting revealed a significant increase of toll-like receptor-4 (TLR-4) in RIP-treated RAW264.7, suggesting that TLR-4 may be associated with the immunomodulatory mechanism of RIP. Animal experiments also demonstrated through ELISA assays a significant increase in IFN- $\gamma$ and IL-10 levels after the splenocytes of RIP-immunized mice were stimulated by
\end{abstract}

Correspondence to: Professor Yan Hong, School of Bioengineering, Hangzhou Medical College, 182 Tianmushan Road, Hangzhou, Zhejiang 310013, P.R. China

E-mail: hongy1008@163.com

Abbreviations: RIP, Radix isatidis polysaccharides; LPS, lipopolysaccharide; SD, standard deviation

Key words: Radix isatidis polysaccharides, RAW264.7 cells, macrophages, splenocytes, innate immunity, immunomodulator inactivated herpes simplex virus type 2 . The immune function of RIP-immunized mice was improved. The present study suggested that RIP could be potentially used as a novel immunomodulator.

\section{Introduction}

Immune modulation serves an important role in maintaining human body health. The use of immunomodulators can enhance host defence, especially for patients with cancer and those that are immunocompromised (1). Several types of immunomodulators have been identified, including granulocyte colony-stimulating factor, IFN- $\gamma$ and numerous components extracted from microorganisms, such as glucose polymers from the cell wall of certain pathogenic bacteria and collagenases of bacterial metabolites (2-5). In recent decades, natural polysaccharides isolated from Chinese herbal medicines have also attracted much attention in the biopharmaceutical field and, in certain cases, have been revealed to improve the immune function of patients. It was reported that the polysaccharides isolated from Chinese herbal medicines are relatively non-toxic and do not cause significant side effects compared with the immunomodulating polysaccharides derived from microorganisms and chemical synthesis $(1,6)$.

Polysaccharides are a group of natural macromolecular polymers composed of $>10$ monosaccharides that are linked by glycosidic bonds. Since the 1990s, scientists have identified that numerous water-soluble polysaccharides extracted from plants can promote T-cell proliferation (7). A number of studies have documented that polysaccharides can exhibit a variety of biological functions, including immune regulation, anti-inflammatory responses, anti-viral functions and anti-tumor effects, regulating the immune system in numerous ways (8-12).

Similar to other Chinese herbal medicines, Radix isatidis (R. isatidis) polysaccharides (RIPs) exhibit immunomodulatory effects. $R$. isatidis is one of the most commonly used traditional Chinese herbal medicines from the roots of Isatis indigotica Fort. (family, Cruciferae) and has been used for thousands of years in China (13). The sliced and dried roots are manufactured into granules or syrups, then dissolved or diluted in hot water to treat febrile disease by clearing heat and reducing swelling (13). Different chemical constituents of $R$. isatidis have been isolated, including alkaloids, nucleosides, amino acids, organic acids, sterols, flavonoids, lignanoids, 
volatile oils and polysaccharides (14). Among these, RIP has been demonstrated to serve broad antiviral activity (15-18), immunomodulation (19-21), antioxidant activity and anti-inflammatory activity (22).

RIP regulates the immune system by activating dendritic cells, natural killer (NK) cells, macrophages and lymphocytes $(21,23,24)$. RIPs can promote the proliferation of NK cells and the expression of IFN- $\gamma$ and TNF- $\alpha(23,24)$. RIPs are also able to accelerate maturation and secretory function of monocyte-derived dendritic cells (21). Furthermore, in immunocompromised mice, RIP can improve the phagocytosis capability of mononuclear macrophages, the transformation of lymphocytes and the production of IL- 2 and IFN- $\gamma$ (19). RIP has also been demonstrated to enhance the immune effects of vaccines, leading to adaptive and innate immunity $(25,26)$. An $\alpha$-glucan isolated from $R$. isatidis, immunized with the H1N1 influenza virus and recombinant hepatitis B surface antigen in mice, can positively affect antibody levels and stimulate macrophages proliferation and TNF- $\alpha$ secretion of mouse alveolar macrophage cells (25). Arabinogalactan, another polysaccharide isolated from $R$. isatidis, can also induce T-lymphocyte proliferation in the spleen and high levels of cytokine secretion in mice immunized with inactivated rabies virus (26). In a previous study, purified RIP was demonstrated to induce a Thelper type 1 (Th1) cell-biased adaptive immune response of mice immunized with a herpes simplex virus-2 (HSV-2) DNA vaccine (27).

Toll-like receptors (TLRs) are a family of important pattern-recognition receptors (28). Among TLRs, TLR-4 is essential for many natural polysaccharide-induced activations of macrophages, dendritic cells and B cells, such as Astragalus polysaccharide and Angelica sinensis polysaccharide $(8,29)$. It is currently unknown whether TLR-4 is also a receptor of RIPs. Therefore, the role of TLR-4 in RIPs-induced activation of RAW264.7 cells was investigated in the present study.

The present study aimed to investigate the immunomodulatory effects of RIP on RAW264.7 macrophages and murine splenocytes, including the activation of RAW264.7 cells and the expression of immune-related cytokines, and attempted to identify the mechanism of immunomodulation. These findings could provide scientific evidence for the use of RIP as an immunomodulator.

\section{Materials and methods}

Materials. R. isatidis powder was purchased from Qixin Chinese Medicine Granules Co., Ltd. (cat. no. 2016-0041). DMEM high-glucose (cat. no. MA0571) and Trypsin-EDTA (cat. no. MB4376) were purchased from Dalian Meilun Biotechnology Co., Ltd. RPMI-1640 (cat. no. 11875093), Antibiotic-Antimycotic (100X; cat. no. 15240096) and fetal bovine serum (FBS; cat. no. 16000-044), were purchased from Gibco (Thermo Fisher Scientific, Inc.). The Griess reagent I and Griess Reagent II (cat. no. S0021) were purchased from Shanghai Beyotime Biotechnology Research Institute, Shanghai, China. Lipopolysaccharide (LPS; cat. no. L2880) was purchased from Sigma-Aldrich (Merck KGaA). The CellTiter $96^{\circledR} \mathrm{AQ}$ uеous One Solution Cell Proliferation Assay was purchased from Promega Corp. (cat. no. G3580). IFN- $\gamma$ Mouse 'Femto-HS' High Sensitivity Uncoated ELISA (cat. no. 88-8314), IL-10
Mouse Uncoated ELISA (cat. no. 88-7105), TNF- $\alpha$ Mouse Uncoated ELISA (cat. no. 88-7324), IL-6 Mouse ELISA Kit (cat. no. BMS603-2TEN), Pierce ${ }^{\mathrm{TM}}$ Coomassie (Bradford) Protein Assay kit (cat. no. 23200), TLR-4 monoclonal antibody (mAb; cat. no. MA5-16216) and $\beta$-actin mAb (cat. no. MA5-15452) were all purchased from Invitrogen (Thermo Fisher Scientific, Inc.). RAW264.7 macrophages were purchased from Cell Bank of Type Culture Collection of The Chinese Academy of Sciences. A total of 16 specific-pathogen-free female BALB/c mice (age, 8 weeks; weight, 20-22 g; Sino-British SIPPR/BK Lab Animal Ltd.) were kept in a temperature-controlled room (temperature, $18-29^{\circ} \mathrm{C}$; relative humidity, $40-70 \%$ ) under a $12 \mathrm{~h}$ light/dark cycle with free access to food and water. All animal procedures were approved and carried out in accordance with the Institutional Guidelines for Animal Experiments of the Animal Care and Use Committee at the Zhejiang Academy of Medical Sciences [Hangzhou, China; approval no. SYXK (Zhe) 2017-0008].

RIP preparation. RIP was extracted by water extraction and alcohol precipitation. The extraction procedure was performed as previously described (27). $R$. isatidis $(2 \mathrm{~g})$ powder in $30 \mathrm{ml}$ distilled water was incubated in a thermostatic water bath at $55^{\circ} \mathrm{C}$ overnight. Following filtration through defatted cotton, the suspension was centrifuged $2,000 \mathrm{xg}$ for $10 \mathrm{~min}$ at $4^{\circ} \mathrm{C}$ by Allegra X-12 centrifuge (Beckman Coulter, Inc.) to remove residues. The supernatant was concentrated via rotary evaporation and precipitated with $95 \%$ alcohol for $72 \mathrm{~h}$ at room temperature, followed by centrifugation at $2,000 \mathrm{xg}$ for $10 \mathrm{~min}$ at $4^{\circ} \mathrm{C}$. The precipitates were redissolved and dialyzed for $48 \mathrm{~h}$ at room temperature. The non-dialysate was lyophilized using Heto PowerDry LL3000 (Thermo Fisher Scientific, Inc.) at $-40^{\circ} \mathrm{C}$ for $48 \mathrm{~h}$ to obtain RIPs. The carbohydrate content of RIP was determined using the phenol-sulfuric acid method with glucose as a standard, as previously described (30). The protein content of RIP was determined using a Bradford Assay with BSA (cat. no. C506031; Sangon Biotech Co., Ltd.; $25-2,000 \mu \mathrm{g} / \mathrm{ml})$ as a standard.

Cell culture. RAW264.7 cells were cultured in high-glucose DMEM containing $10 \% \mathrm{FBS}$ at $37^{\circ} \mathrm{C}$ and $5 \% \mathrm{CO}_{2}$ under saturated humidity.

RIP cytotoxicity. RIP cytotoxicity was quantified using cell viability. RAW264.7 cells $\left(2 \times 10^{4}\right.$ cells/well $)$ were cultured at $37^{\circ} \mathrm{C}$ in 96 -well plates with $200 \mu 110 \%$ FBS high-glucose DMEM for $24 \mathrm{~h}$ and $5 \% \mathrm{CO}_{2}$ under saturated humidity, and then incubated at $37^{\circ} \mathrm{C}$ with different concentrations of RIP $(0.02,0.04,0.08,0.16,0.32,0.63,1.25,2.5,5$ and $10 \mathrm{mg} / \mathrm{ml})$ in high-glucose DMEM for $24 \mathrm{~h}$. Cell viability was determined using the CellTiter $96^{\oplus} \mathrm{AQ}$ ueous One Solution Cell Proliferation Assay. Briefly, $40 \mu \mathrm{l} /$ well CellTiter $96^{\circledR} \mathrm{AQ}_{\text {ueous }}$ One Solution reagent was added to the 96-well plates and incubated for $4 \mathrm{~h}$ at $37^{\circ} \mathrm{C}$. The optical density (OD) value at a wavelength of $490 \mathrm{~nm}$ was analysed using Epoch Microplate Spectrophotometer (BioTek Instruments, Inc.). High-glucose DMEM alone served as negative control.

Morphological change of RAW264.7 cells. RAW264.7 cells $\left(1 \times 10^{6}\right.$ cells/well) were cultured in 6 -well plates for $24 \mathrm{~h}$ at 


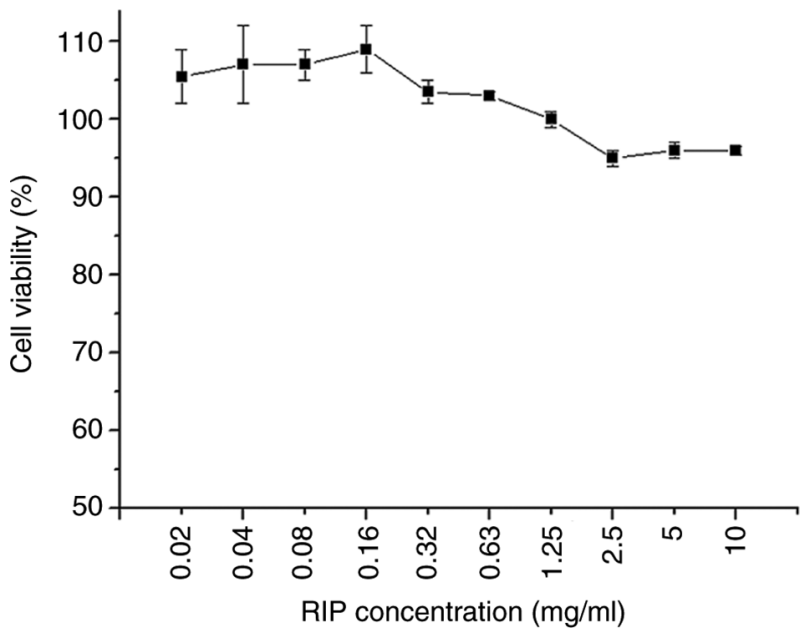

Figure 1. Cytotoxicity of RIP in RAW264.7 cells. RAW264.7 cells were treated with different concentrations of RIP from 0.02 to $10 \mathrm{mg} / \mathrm{ml}$ for $24 \mathrm{~h}$. Cell viability was determined using the CellTiter $96^{\circledR} \mathrm{AQueous}$ One Solution Cell Proliferation Assay. High-glucose DMEM containing 10\% FBS served as negative control. Data are presented as the mean \pm SD $(n=3)$. RIP, Radix isatidis polysaccharide.

$37^{\circ} \mathrm{C}$ and $5 \% \mathrm{CO}_{2}$ under saturated humidity. Cells were then treated with different concentrations of RIP $(0,0.08,0.32$, 1.25 and $5 \mathrm{mg} / \mathrm{ml})$ or LPS $(2 \mu \mathrm{g} / \mathrm{ml})$ for $24 \mathrm{~h}$. Morphological changes were observed using a phase-contrast microscope (magnification, 20x; Olympus Corporation).

Nitric oxide $(\mathrm{NO})$ production . RAW264.7 cells ( $1 \times 10^{6}$ cells/well) were cultured in six-well plates with $3 \mathrm{ml} 10 \% \mathrm{FBS}$ high-glucose DMEM for $24 \mathrm{~h}$ at $37^{\circ} \mathrm{C}$ and $5 \% \mathrm{CO}_{2}$ under saturated humidity. RAW264.7 cells were then incubated at $37^{\circ} \mathrm{C}$ with different concentrations of RIP $(0,0.08,0.32,1.25$ and $5 \mathrm{mg} / \mathrm{ml})$ or LPS $(2 \mu \mathrm{g} / \mathrm{ml})$ for $24 \mathrm{~h}$. NO production in cells was measured by the Griess method according to the instructions provided by the manufacturer (31). Briefly, the cell culture media of the six-well plates were centrifuged $(200 \mathrm{x}$ g for $5 \mathrm{~min})$ at $4^{\circ} \mathrm{C}$, the supernatant $(50 \mu \mathrm{l})$ was distributed in 96-well plate, and $50 \mu \mathrm{l}$ /well Griess reagent I and $50 \mu \mathrm{l} /$ well Griess reagent II were added. The reaction was allowed to proceed for $10 \mathrm{~min}$ at room temperature. The absorbance was read at $540 \mathrm{~nm}$ using Epoch Microplate Spectrophotometer, and the concentrations of $\mathrm{NO}_{2}{ }^{-}$were determined using a least squares linear regression analysis of the sodium nitrite standard curve.

Mice immunization and sample collection. All 16 female mice were randomly divided into two groups ( 8 mice/group) and immunized intramuscularly in their hind legs on day 0 . Animals were treated with $50 \mu$ l per hind leg of PBS (PBS group) or with RIP (1 mg/ml; RIP group). On day 14 , all mice were injected a second time. The body weight of experimental animals was measured every day until the end of the experiment. The animals were euthanized when the defined humane endpoint requirements were met: $>15 \%$ loss of body weight within 1-2 days or $>20 \%$ loss of body weight overall (32). On day 28 , mice were humanely euthanized via intraperitoneal injection of pentobarbital sodium $(50 \mathrm{mg} / \mathrm{kg}$ ) followed by cervical dislocation (33). Animal death was confirmed by the cessation of heartbeat and respiration. The spleens of mice were collected under sterile conditions. A single-cell suspension of splenocytes was prepared in RPMI-1640 supplemented with 10\% FBS and $1 \mathrm{X}$ Antibiotic-Antimycotic at $37^{\circ} \mathrm{C}$ and $5 \% \mathrm{CO}_{2}$ under saturated humidity.

ELISA for the quantitative analysis of cytokines. RAW264.7 cells $\left(2 \times 10^{5}\right.$ cells/well $)$ were seeded into a 96-well plate and cultured for $24 \mathrm{~h}$ at $37^{\circ} \mathrm{C}$ and $5 \% \mathrm{CO}_{2}$ under saturated humidity. Cells were subsequently incubated at $37^{\circ} \mathrm{C}$ with different concentrations of RIP $(0.08,0.32,1.25$ and $5 \mathrm{mg} / \mathrm{ml})$ or LPS $(2 \mu \mathrm{g} / \mathrm{ml})$ in high-glucose DMEM containing $10 \%$ FBS for $24 \mathrm{~h}$. TNF- $\alpha$ and IL-6 levels were determined by ELISA according to the manufacturer's instructions. Splenocytes $\left(2 \times 10^{6}\right.$ cells/well $)$ were seeded into a 96-well plate and stimulated with inactivated HSV-2 $(50 \mu \mathrm{g} / \mathrm{ml})$ in RPMI-1640 containing 10\% FBS and $1 \mathrm{X}$ Antibiotic-Antimycotic or RPMI-1640 containing 10\% FBS and $1 \mathrm{X}$ Antibiotic-Antimycotic only (negative control) and incubated at $37^{\circ} \mathrm{C}$ for $48 \mathrm{~h}$. IFN- $\gamma$ and IL-10 levels of culture supernatant were then determined by ELISA according to the manufacturer's instructions. The absorbance was measured at $450 \mathrm{~nm}$ using Epoch Microplate Spectrophotometer.

Western blotting. RAW264.7 cells $\left(3 \times 10^{6}\right.$ cells/well) were seeded into a six-well plate and cultured in high-glucose DMEM containing $10 \% \mathrm{FBS}$ for $24 \mathrm{~h}$ at $37^{\circ} \mathrm{C}$ and $5 \% \mathrm{CO}_{2}$ under saturated humidity, then incubated at $37^{\circ} \mathrm{C}$ with different concentrations of RIP $(0.08,0.32,1.25$ and $5 \mathrm{mg} / \mathrm{ml})$ or LPS $(2 \mu \mathrm{g} / \mathrm{ml})$ in high-glucose DMEM containing 10\% FBS for 24 h. RAW264.7 cells were subsequently washed twice with PBS and lysed with Mammalian Cell Total Protein Lysis Buffer (cat. no. CW0889M; CoWin Biosciences). Total protein was quantified using Pierce ${ }^{\mathrm{TM}}$ Coomassie (Bradford) Protein Assay kit using BSA as a standard. Proteins (4.5 $\mu \mathrm{g} / \mathrm{sample})$ were separated by $10-12 \%$ SDS-PAGE and transferred to PVDF membranes. Membranes were blocked with 5\% skimmed milk in TBS containing $0.05 \%$ Tween-20 (TBST) at $37^{\circ} \mathrm{C}$ for $1 \mathrm{~h}$. The membranes were incubated with the following primary monoclonal antibodies in TBST containing $1 \%$ skimmed milk at $4^{\circ} \mathrm{C}$ overnight: TLR-4 (1:300) and $\beta$-actin $(1: 10,000)$. After washing the membrane with TBST for a total of three times, the membranes were incubated with HRP-conjugated goat-anti-mouse IgG $(1: 5,000)$ secondary antibodies (cat no. D110087; Sangon Biotech Co., Ltd.) at $37^{\circ} \mathrm{C}$ for $2 \mathrm{~h}$. After washing the membrane with TBST for a total of five times, the membranes were treated with the W (western blot)-TMB Chromogenic Reagent kit (cat. no. C510025; Sangon Biotech Co., Ltd.) at $37^{\circ} \mathrm{C}$ for $15 \mathrm{~min}$. Protein bands were visualized and imaged by western blotting imaging system (Peiqing Science \& Technology Co., Ltd.). ImageJ software v1.8.0 (National Institutes of Health) was used to analyze the relative protein expression levels of TLR-4 (97 kDa), with $\beta$-actin (42 kDa) as the loading control.

Statistical analysis. All in vitro experiments were performed in triplicate. A total of 8 mice per group were used for in vivo experiments. GraphPad Prism 5.0 software (GraphPad Software, Inc.) was used for data analysis. Data are presented as the mean \pm SD. An unpaired Student's t-test was used make 

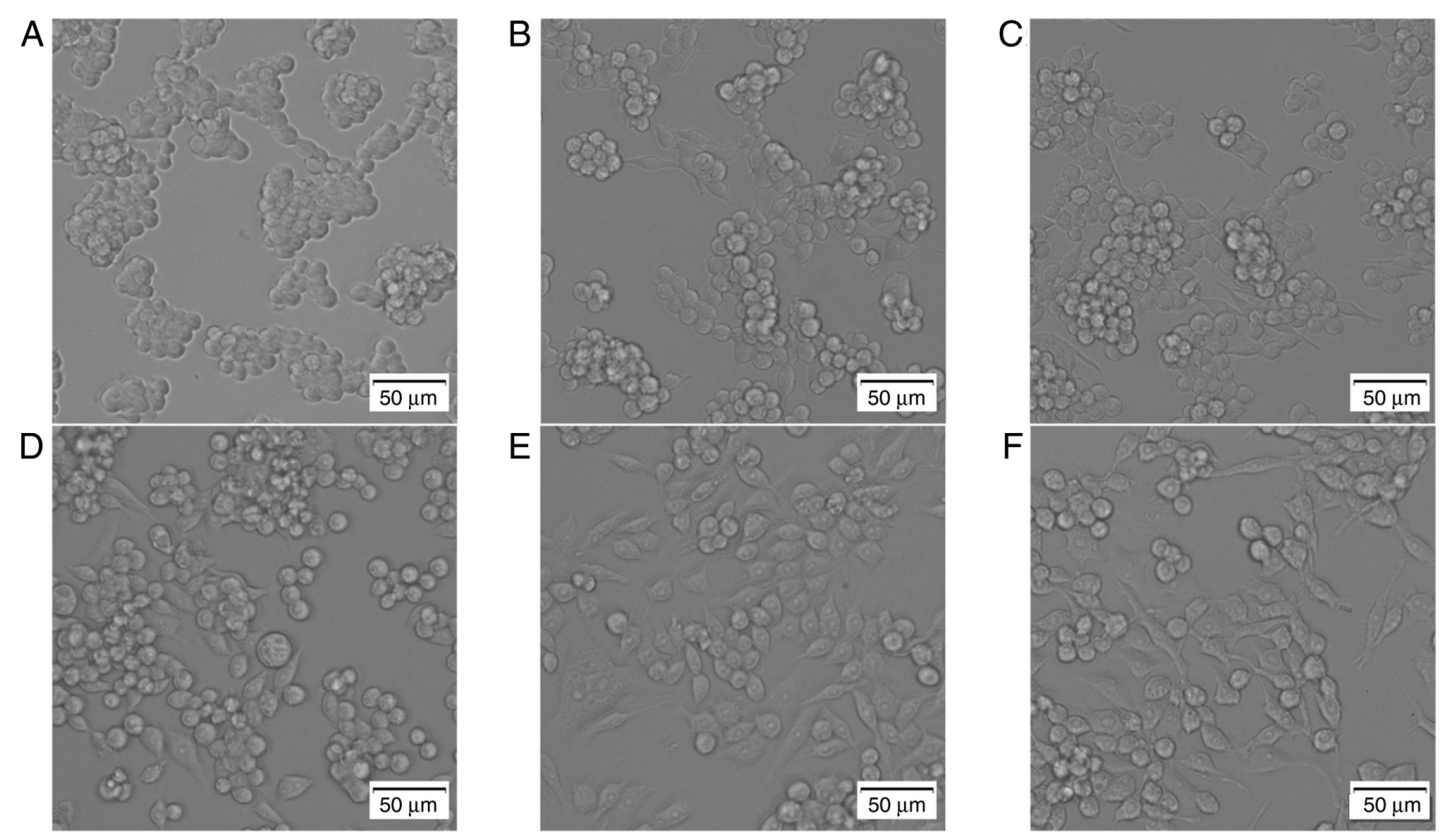

Figure 2. RIP-induces morphological changes in RAW264.7 cells. Cells were treated with RIP $(0.08,0.32,1.25$ and $5 \mathrm{mg} / \mathrm{ml})$, LPS $(2 \mu \mathrm{g} / \mathrm{ml})$ or high-glucose DMEM containing 10\% FBS alone for $24 \mathrm{~h}$. Morphological changes were observed using a phase-contrast microscope. The images are as follows: (A) control, (B) $0.08 \mathrm{mg} / \mathrm{ml} \mathrm{RIP,} \mathrm{(C)} 0.32 \mathrm{mg} / \mathrm{ml}$ RIP, (D) $1.25 \mathrm{mg} / \mathrm{ml} \mathrm{RIP,} \mathrm{(E)} 5 \mathrm{mg} / \mathrm{ml}$ RIP and (F) LPS. The experiment had three independent repeats. RIP, Radix isatidis polysaccharide; LPS, lipopolysaccharide.
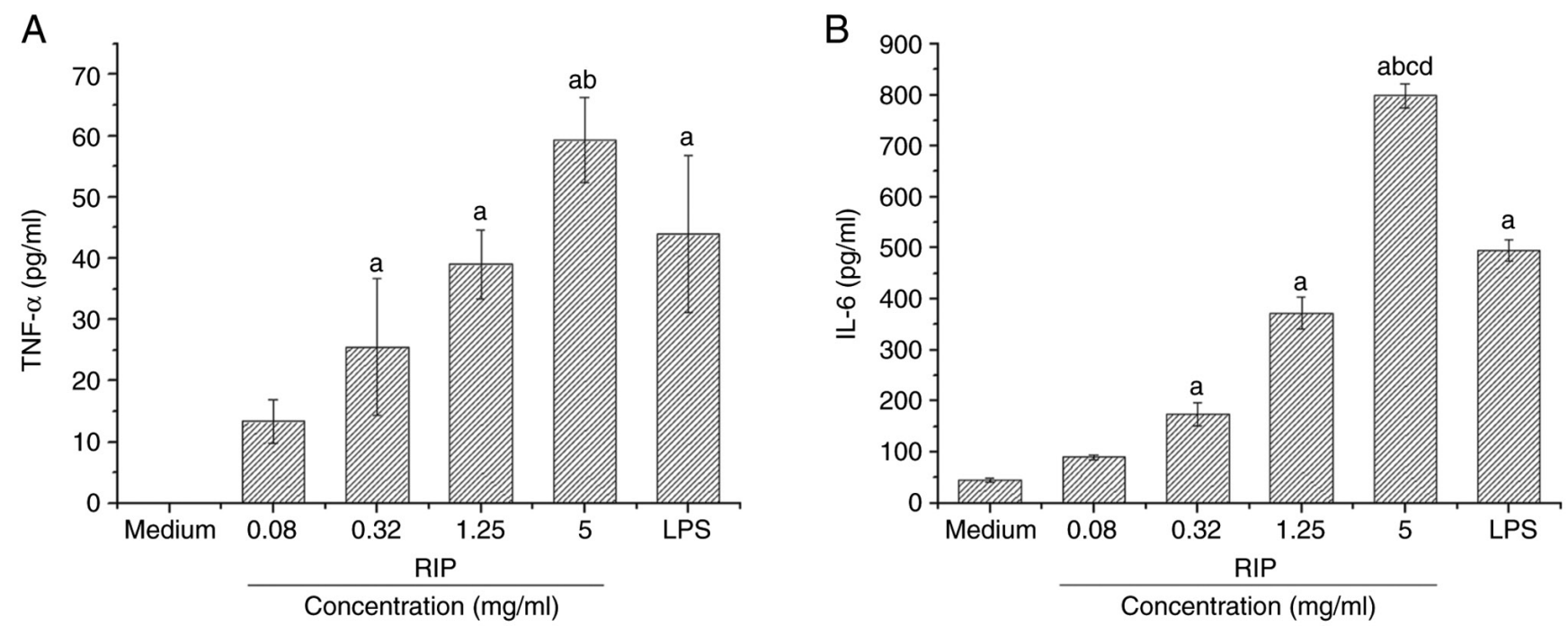

Figure 3. Effects of RIP on the production of TNF- $\alpha$ and IL-6 in RAW264.7 cells. RAW 264.7 cells were treated with RIP $(0.08,0.32,1.25 \mathrm{and} 5 \mathrm{mg} / \mathrm{ml}), \mathrm{LPS}$ $(2 \mu \mathrm{g} / \mathrm{ml})$ or DMEM only for $24 \mathrm{~h}$. The culture supernatants of RAW264.7 cells were collected for detection of (A) TNF- $\alpha$ and (B) IL-6 by ELISA. All data are presented as the mean $\pm \mathrm{SD}(\mathrm{n}=3)$. The optical density values of TNF- $\alpha$ in the medium control group were not found within the standard curve and lower than the detection sensitivity. ${ }^{a}<<0.01$ vs. medium control; ${ }^{\mathrm{b}} \mathrm{P}<0.05$ vs. all other RIP concentrations; ${ }^{\mathrm{c}} \mathrm{P}<0.05$ vs. LPS; and ${ }^{\mathrm{d}} \mathrm{P}<0.05 \mathrm{vs} .1 .25 \mathrm{mg} / \mathrm{ml} \mathrm{RIP}$. RIP, Radix isatidis polysaccharide; LPS, lipopolysaccharide.

statistical comparisons between two groups, and one-way ANOVA followed by Dunnett's or Tukey's post hoc tests were used to make statistical comparisons between three or more groups. $\mathrm{P}<0.05$ was considered to indicate a statistically significant difference.

\section{Results}

RIP characterization. The obtained RIPs were water soluble polysaccharides. We established in a previous study a glucose standard curve using the phenol-sulfuric acid method: The linear regression equation was $y=0.0069 x+0.0397$ [with $\mathrm{x}$ the mass of glucose $(\mu \mathrm{g})$ and $\mathrm{y}$ the OD value at $450 \mathrm{~nm}$; $\mathrm{R}^{2}=0.9955$ (27). The carbohydrate content of RIP was $87.5 \%$ (100 mg crude polysaccharides contained $87.5 \mathrm{mg}$ glucose). Using the Bradford protein assay, absorbance at $595 \mathrm{~nm}$ was 0.009 , which was not within the BSA standard curve $(25-2,000 \mu \mathrm{g} / \mathrm{ml})$ and the protein content of RIP was lower than the detection sensitivity. The protein content was therefore considered to be weak. 
Table I. NO production following RIP treatment.

\begin{tabular}{lc}
\hline $\begin{array}{l}\text { Treatment } \\
\text { concentration, mg/ml }\end{array}$ & $\begin{array}{c}\text { NO concentration } \\
(\mu \mathrm{M} ; \text { mean } \pm \mathrm{SD} ; \mathrm{n}=3)\end{array}$ \\
\hline Medium & $0.00 \pm 0.00$ \\
RIP & \\
0.08 & $0.98 \pm 0.18$ \\
0.32 & $13.10 \pm 0.33^{\mathrm{a}}$ \\
1.25 & $17.38 \pm 0.50^{\mathrm{a}, \mathrm{b}}$ \\
5.00 & $12.85 \pm 0.33^{\mathrm{a}}$ \\
LPS & \\
0.002 & $59.16 \pm 2.97^{\mathrm{a}}$ \\
\hline
\end{tabular}

${ }^{\mathrm{a}} \mathrm{P}<0.01$ vs. medium control; ${ }^{\mathrm{b}} \mathrm{P}<0.01$ vs. $0.08,0.32$ and $5 \mathrm{mg} / \mathrm{ml}$ RIP. Data are presented as the mean \pm SD $(n=3)$. NO, nitric oxide; RIP, Radix isatidis polysaccharide; LPS, lipopolysaccharide.

Table II. IFN- $\gamma$ and IL-10 levels in immunized mice.

\begin{tabular}{lcc}
\hline & \multicolumn{2}{c}{ Mean \pm SD $(\mathrm{n}=8)$} \\
\cline { 2 - 3 } Treatment & IFN- $\gamma, \mathrm{pg} / \mathrm{ml}$ & IL-10, $\mathrm{pg} / \mathrm{ml}$ \\
\hline PBS & $6.20 \pm 1.64$ & $265.83 \pm 53.60$ \\
RIP $(1 \mathrm{mg} / \mathrm{ml})$ & $36.64 \pm 6.16^{\mathrm{a}}$ & $1,342.83 \pm 175.46^{\mathrm{a}}$ \\
\hline
\end{tabular}

${ }^{\mathrm{a}} \mathrm{P}<0.01$ vs. PBS group. RIP, Radix isatidis polysaccharide.

RIP cytotoxicity. RIP cytotoxicity on RAW264.7 cells was examined (Fig. 1). RAW264.7 cell viability was almost $100 \%$ when RIP concentration was $\leq 1.25 \mathrm{mg} / \mathrm{ml}$, demonstrating that RIPs had no cytotoxicity. Increasing the RIP concentration up to $10 \mathrm{mg} / \mathrm{ml}$ decreased cell viability; however, cell viability remained $>95 \%$, further demonstrating that RIP had a low cytotoxicity. The water-soluble RIPs extracted from $R$. isatidis, like other plant polysaccharides, had a low cytotoxicity (14). Therefore, $0.08,0.32,1.25$ and $5 \mathrm{mg} / \mathrm{ml}$ of RIP were chosen for subsequent studies.

Morphological changes of RAW264.7 cells. Following the addition of LPS and different concentrations of RIP to RAW264.7 cells, morphological changes were observed. In the control group, the RAW264.7 cells were round and clumped together (Fig. 2A). The RAW264.7 cells treated with different concentrations of RIP all displayed morphological changes in a dose-dependent manner. In the $0.08 \mathrm{mg} / \mathrm{ml} \mathrm{RIP-treated} \mathrm{group,}$ the cellular morphology was almost the same as the control group and cells were clustered together, only a few cells has a spindle-like shape (Fig. 2B). In the $0.32 \mathrm{mg} / \mathrm{ml}$ RIP-treated group, approximately one fourth of the cells were spindle-like but the round cells still clustered together (Fig. 2C). In the $1.25 \mathrm{mg} / \mathrm{ml}$ RIP group, almost half of the cells were spindle-like and independent, not aggregating in groups (Fig. 2D). In the $5 \mathrm{mg} / \mathrm{ml}$ RIP-treated group, most of the cells were spindle-like or polygonal in shape and were more dispersed (Fig. 2E). The

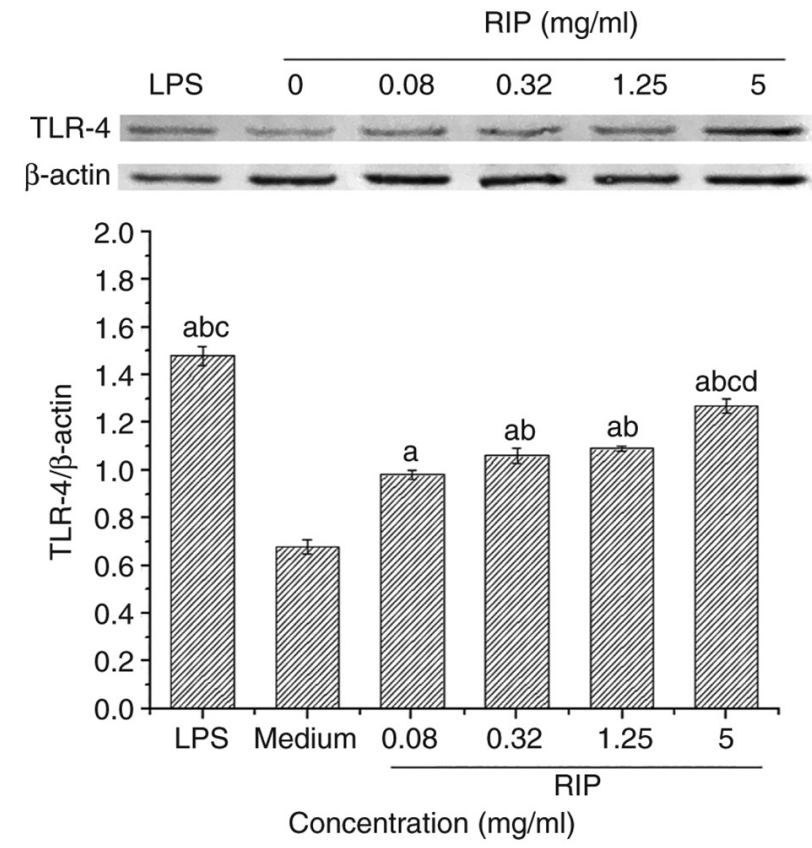

Figure 4. RIP-induced TLR-4 protein expression in RAW264.7 cells. TLR-4 protein expression levels were determined via western blotting. ImageJ was used to semi-quantify the relative expression level of TLR-4. Data are presented as the mean $\pm \mathrm{SD}(\mathrm{n}=3)$. ${ }^{\mathrm{a}} \mathrm{P}<0.01$ vs. medium control; ${ }^{\mathrm{b}} \mathrm{P}<0.05$ vs. $0.08 \mathrm{mg} / \mathrm{ml} ;{ }^{\mathrm{c}} \mathrm{P}<0.05$ vs. $0.32 \mathrm{mg} / \mathrm{ml} \mathrm{RIP}$; and ${ }^{\mathrm{d}} \mathrm{P}<0.05$ vs. LPS. RIP, Radix isatidis polysaccharide; TLR-4, toll-like receptor 4; LPS, lipopolysaccharide.

morphological changes seen in the $5 \mathrm{mg} / \mathrm{ml}$ RIP treated group were the same as the LPS-treated group (Fig. 2F).

NO production. RIP $(0.08,0.32,1.25$ and $5 \mathrm{mg} / \mathrm{ml})$ stimulated RAW264.7 cells to produce NO as demonstrated in Table I. A RIP concentration of $1.25 \mathrm{mg} / \mathrm{ml}$ produced the highest significant concentration of NO $(17.38 \pm 0.50 \mu \mathrm{M})$ in RAW264.7 cells compared with the medium control and all other RIP concentrations $(\mathrm{P}<0.01)$. LPS stimulated RAW264.7 cells to produce $59.16 \pm 2.97 \mu \mathrm{M}$ NO.

TNF- $\alpha$ and IL- 6 levels in RIP-treated RAW264.7 cells. RIP-stimulated $(0.08,0.32,1.25$ and $5 \mathrm{mg} / \mathrm{ml})$ RAW264.7 cells produced TNF- $\alpha$ in a dose-dependent manner, with $5 \mathrm{mg} / \mathrm{ml} \mathrm{RIP}$ inducing the highest significant level of TNF- $\alpha$ compared with the control and all other RIP concentrations ( $\mathrm{P}<0.01$; Fig. 3A). RIP-stimulated $(0.08,0.32,1.25$ and $5 \mathrm{mg} / \mathrm{ml})$ RAW264.7 cells also produced IL- 6 in a dose-dependent manner, with $5 \mathrm{mg} / \mathrm{ml}$ RIP inducing the highest significant level of IL- 6 compared with the other RIP samples and LPS $(2 \mu \mathrm{g} / \mathrm{ml}$; P $<0.01$; Fig. 3B).

TLR-4 protein expression levels. TLR-4 protein expression levels in RAW264.7 cells treated with $0.08,0.32,1.25$ and $5 \mathrm{mg} / \mathrm{ml}$ RIP were examined using western blotting. TLR-4 protein expression levels increased in a dose-dependent manner and were significantly higher compared with the medium control group ( $\mathrm{P}<0.01$; Fig. 4). LPS-treated RAW264.7 cells expressed the highest levels of TLR-4.

IL-10 and IFN- $\gamma$ levels in RIP-treated splenocytes. Splenocytes were obtained from RIP-treated mice on day 28 
and stimulated by inactivated HSV-2. The levels of IFN- $\gamma$ and IL-10 in the RIP group were significantly higher compared with the PBS group $(\mathrm{P}<0.01$; Table II).

\section{Discussion}

Immunomodulation is regarded as a vital treatment strategy for enhancing the body's immune defense in patients with cancer and in those that are immunocompromised. Macrophages are the first line of defense against infections and are positioned throughout the tissues of the body (34). The immunomodulatory functions of macrophages include macrophage proliferation, phagocytic activity, the release of cytotoxic and inflammatory molecules such as $\mathrm{NO}$ and the release of pro-inflammatory cytokines including TNF- $\alpha$, IL-1 $\beta$ and IL-6 (8,35-38). In the present study, RIP induced morphological changes in RAW264.7 cells in a dose-dependent manner. The emergence of the dendritic-like morphology of macrophages may reflect their activation (39). During this possible activation, the activated RAW264.7 cells produced NO, TNF- $\alpha$ and IL- 6 . However, when the RIP concentration was $5 \mathrm{mg} / \mathrm{ml}$, the production of $\mathrm{NO}$ decreased: It may be associated with the high concentration of RIP.

Previous studies have demonstrated that RIP has adjuvant properties, elicited by the combined secretion of both Th1 and Th2 cytokines $(19,27)$. In the present study, it was also demonstrated that RIP-injected mice had splenocytes with enhanced immune function when injected with inactive HSV-2 as a foreign stimulus. Following splenocyte stimulation by inactivated HSV-2, levels of IFN- $\gamma$ and IL-10 were significantly increased compared with PBS-treated mice. Škrnjug et al (40) and Ning et al (41) also demonstrated this using a similar approach. IFN- $\gamma$ is produced by Th1 cells and promotes the expression of major histocompatibility complex molecules through activation of macrophages. IFN- $\gamma$ also enhances natural killer cell activity and regulates B cell function (42). IL-10 has stimulatory effects on B cells, including the promotion of B cell survival $(43,44)$ and the stimulation of B cell proliferation and differentiation (45-47). There is evidence that a mixed Th1/Th2 response, characterized by IL-10 production, may enhance pathogen clearance $(48,49)$. In the present study, mice were injected with a single dose of RIP. Further studies should consider the RIP dose gradient used in the current study for murine immunization. The immune function of RIP-immunized mice may possibly have been enhanced. The results may provide the foundations for the further development of an immunomodulator.

LPS is a major macrophage activation factor and is widely used as an in vitro inflammatory model (50). On the membrane of RAW264.7 cells, LPS binds to CD14 receptors and further recognizes TLR-4 (51). TLR-4 requires myeloid differentiation factor 2 to form a complex for effective LPS recognition and downstream activation of the NF- $\mathrm{kB}$ signaling pathway (51). The present study demonstrated the mechanisms of RIP-mediated activation and an increase in the relative expression level of TLR-4 in RIP-treated RAW264.7 cells in a dose-dependent manner. As this is only preliminary research, more molecules within this signaling pathway should be investigated in the context of this study.

The complexity of polysaccharide composition, including chemical composition, molecular weight, glycosidic linkage and the degree of branching, influences the application of polysaccharides (52). Previous studies of polysaccharides have focused on their extraction and purification. Two purified polysaccharides, an $\alpha$-glucan and an arabinogalactan isolated from $R$. isatidis, both have immunoadjuvant potential $(25,26)$. Based on these studies, future work will focus on purified polysaccharides, such as the comparison of the immunostimulatory effects between purified polysaccharides and mixed polysaccharides.

In conclusion, the immunomodulatory effects of RIP included the activation of RAW264.7 cells and the possible improvement of splenocyte immune function. The present study determined that RIP could potentially be used as a novel immunomodulator.

\section{Acknowledgements}

Not applicable.

\section{Funding}

This work was supported by Scientific Research Fund of Zhejiang Provincial Education Department (Zhejiang, China; grant no. Y202146042).

\section{Availability of data and materials}

The datasets used and/or analyzed during the current study are available from the corresponding author on reasonable request.

\section{Authors' contributions}

YH, WT and TF contributed substantially to the conception and design of the study, the acquisition, analysis, and interpretation of data. HPZ and ZJH contributed substantially to the analysis and interpretation of the data. All authors were involved in the drafting of the manuscript. YH, WT and TF are responsible for confirming the authenticity of all the raw data. All authors agreed to be accountable for all aspects of the work in ensuring that questions related to the accuracy or integrity of any part of the work are appropriately investigated and resolved. All authors have read and approved the final manuscript.

\section{Ethics approval and consent to participate}

All animal procedures were approved and carried out in accordance with the Institutional Guidelines for Animal Experiments of the Animal Care and Use Committee at the Zhejiang Academy of Medical Sciences [Hangzhou, China; approval no. SYXK (Zhe) 2017-0008].

\section{Patient consent for publication}

Not applicable.

\section{Competing interests}

The authors declare that they have no competing interests. 


\section{References}

1. Tzianabos AO: Polysaccharide immunomodulators as therapeutic agents: structural aspects and biologic function. Clin Microbiol Rev 13: 523-533, 2000.

2. Murray HW: Current and future clinical applications of interferon-gamma in host antimicrobial defense. Intensive Care Med 22 (Suppl 4): S456-S461, 1996.

3. Nemunaitis J: A comparative review of colony-stimulating factors. Drugs 54: 709-729, 1997.

4. Hamilton JA and Anderson GP: GM-CSF biology. Growth Factors 22: 225-231, 2004.

5. Singh N and Bhattacharyya D: Collagenases in an ether extract of bacterial metabolites used as an immunostimulator induces TNF- $\alpha$ and IFN- $\gamma$. Int Immunopharmacol 23: 211-221, 2014

6. Wasser SP: Medicinal mushrooms as a source of antitumor and immunomodulating polysaccharides. Appl Microbiol Biotechnol 60: 258-274, 2002.

7. Li XY: Immunomodulating Chinese herbal medicines. Mem Inst Oswaldo Cruz 86 (Suppl 2): S159-S164, 1991

8. Wei W, Xiao HT, Bao WR, Ma DL, Leung CH, Han XQ, Ko CH, Lau CB, Wong CK, Fung KP, et al: TLR-4 may mediate signaling pathways of Astragalus polysaccharide RAP induced cytokine expression of RAW264.7 cells. J Ethnopharmacol 179: 243-252, 2016.

9. Hou C, Chen L, Yang L and Ji X: An insight into anti-inflammatory effects of natural polysaccharides. Int J Biol Macromol 153: 248-255, 2020

10. Chen X, Han W, Wang G and Zhao X: Application prospect of polysaccharides in the development of anti-novel coronavirus drugs and vaccines. Int J Biol Macromol 164: 331-343, 2020

11. Cai Z, Li W, Wang H, Yan W, Zhou Y, Wang G, Cui J and Wang F: Anti-tumor and immunomodulating activities of a polysaccharide from the root of Sanguisorba officinalis L. Int J Biol Macromol 51: 484-488, 2012

12. Yu Y, Shen M, Song Q and Xie J: Biological activities and pharmaceutical applications of polysaccharide from natural resources: A review. Carbohydr Polym 183: 91-101, 2018.

13. Zhou W and Zhang XY: Research progress of Chinese herbal medicine Radix isatidis (banlangen). Am J Chin Med 41: 743-764, 2013

14. Sun B, Yu S, Zhao D, Guo S, Wang X and Zhao K: Polysaccharides as vaccine adjuvants. Vaccine 36: 5226-5234, 2018.

15. Li Z, Li L, Zhou H, Zeng L, Chen T, Chen Q, Zhou B, Wang Y, Chen Q, Hu P and Yang Z: Radix isatidis polysaccharides inhibit influenza a virus and influenza A virus-induced inflammation via suppression of host TLR3 signaling in vitro. Molecules 22: 116,2017

16. Wei ZY, Wang XB, Zhang HY, Yang CH, Wang YB, Xu DH Chen HY and Cui BA: Inhibitory effects of indigowoad root polysaccharides on porcine reproductive and respiratory syndrome virus replication in vitro. Antivir Ther 16: 357-363, 2011.

17. Wang T, Wang X, Zhuo Y, Si C, Yang L, Meng L and Zhu B Antiviral activity of a polysaccharide from Radix isatidis (Isatis indigotica Fortune) against hepatitis B virus (HBV) in vitro via activation of JAK/STAT signal pathway. J Ethnopharmacol 257: 112782, 2020.

18. Liao HF, Lu MC, Chang HC, Wei CC, Kao CH, Chen $\mathrm{ZH}$, Huang CC and Li C: Effects of herbal medicinal formulas on suppressing viral replication and modulating immune responses. Am J Chin Med 38: 173-190, 2010.

19. Zhao YL, Wang JB, Shan LM, Jin C, Ma L and Xiao XH: Effect of Radix isatidis polysaccharides on immunological function and expression of immune related cytokines in mice. Chin J Integr Med 14: 207-211, 2008.

20. Ma L, Feng SH, Tang JY, Zhao YL and Xiao XH: Influence of Radix isatidis polysaccharides produced by different preparation technologies on proliferation function of mouse splenic lymphocyte. China Pharm (Chin) 18: 169-171, 2007.

21. Wang X, Chen Z, Chen T, Li X, Huang S, Wang H, Tong C and Liu F: Isatis root polysaccharide promotes maturation and secretory function of monocyte-derived dendritic cells. BMC Complement Med Ther 20: 301, 2020.

22. Du Z, Liu H, Zhang Z and Li P: Antioxidant and anti-inflammatory activities of Radix isatidis polysaccharide in murine alveolar macrophages. Int J Biol Macromol 58: 329-335, 2013.

23. Lian ZY, Hou JS, Sun GR, Zhao BS and Xin GH: Radix isatidis polysaccharide enhances killing effect of NK cells on esophageal cancer cells by promoting expression of NKG2D ligand and its mechanism. Chin J Immunol 36: 965-970, 2020.
24. Li JP, Zhu GH, Yuan Y and Liu MX: Anti-tumor and immune function regulation effects of Radix isatidis polysaccharides in vivo. Nat Prod Res Dev 29: 2010-2016, 2017.

25. Shan J, Sun G, Ren J, Zhu T, Jia P, Qu W, Li Q, Wu J, Ma H, Wen $S$ and Wang Y: An $\alpha$-glucan isolated from root of Isatis indigotica, its structure and adjuvant activity. Glycoconj J 31: 317-326, 2014.

26. Zhang W, Zheng X, Cheng N, Gai W, Xue X, Wang Y, Gao Y, Shan J, Yang S and Xia X: Isatis indigotica root polysaccharides as adjuvants for an inactivated rabies virus vaccine. Int J Biol Macromol 87: 7-15, 2016.

27. Zhou HP, Tao W, Fu T, He ZJ and Hong Y: Influence of isatis root polysaccharide on immune effect of herpes simplex virus type-2 DNA vaccine. Chin J Biol 33: 609-613, 2020 (In Chinese).

28. Lim KH and Staudt LM: Toll-like receptor signaling. Cold Spring Harb Perspect Biol 5: a011247, 2013

29. Yang X, Zhao Y, Wang H and Mei Q: Macrophage activation by an acidic polysaccharide isolated from Angelica sinensis (Oliv.) diels. J Biochem Mol Biol 40: 636-643, 2007.

30. Masuko T, Minami A, Iwasaki N, Majima T, Nishimura S and Lee YC: Carbohydrate analysis by a phenol-sulfuric acid method in microplate format. Anal Biochem 339: 69-72, 2005.

31. Zhu H, Ding X, Hou Y, Li Y and Wang M: Structure elucidation and bioactivities of a new polysaccharide from Xiaojin boletus speciosus frost. Int J Biol Macromol 126: 697-716, 2019.

32. Lilley E, Andrews MR, Bradbury EJ, Elliott H, Hawkins P, Ichiyama RM, Keeley J, Michael-Titus AT, Moon LDF, Pluchino S, et al: Refining rodent models of spinal cord injury. Exp Neurol 328: 113273, 2020.

33. Gao B, Li L, Zhu P, Zhang M, Hou L, Sun Y, Liu X, Peng X and $\mathrm{Gu}$ Y: Chronic administration of methamphetamine promotes atherosclerosis formation in ApoE-/- knockout mice fed normal diet. Atherosclerosis 243: 268-277, 2015.

34. Wynn TA and Vannella KM: Macrophages in tissue repair, regeneration, and fibrosis. Immunity 44: 450-462, 2016.

35. Lee JS, Kwon DS, Lee KR, Park JM, Ha SJ and Hong EK: Mechanism of macrophage activation induced by polysaccharide from Cordyceps militaris culture broth. Carbohydr Polym 120: 29-37, 2015.

36. Yang F, Li X, Yang Y, Ayivi-Tosuh SM, Wang F, Li H and Wang G: A polysaccharide isolated from the fruits of physalis alkekengi L. induces RAW264.7 macrophages activation via TLR2 and TLR4-mediated MAPK and NF- $\mathrm{KB}$ signaling pathways. Int J Biol Macromol 140: 895-906, 2019.

37. Liu X, Xie J, Jia S, Huang L, Wang Z, Li C and Xie M: Immunomodulatory effects of an acetylated cyclocarya paliurus polysaccharide on murine macrophages RAW264.7. Int J Biol Macromol 98: 576-581, 2017

38. Zheng P, Fan W, Wang S, Hao P, Wang Y, Wan H, Hao Z, Liu J and Zhao X: Characterization of polysaccharides extracted from platycodon grandiflorus (Jacq.) A.DC. affecting activation of chicken peritoneal macrophages. Int J Biol Macromol 96: 775-785, 2017.

39. Zhang M, Tian X, Wang Y, Wang D, Li W, Chen L, Pan W, Mehmood S and Chen Y: Immunomodulating activity of the polysaccharide TLH-3 from Tricholomalobayense in RAW264.7 macrophages. Int J Biol Macromol 107: 2679-2685, 2018.

40. Škrnjug I, Guzmán CA and Rueckert C: Cyclic GMP-AMP displays mucosal adjuvant activity in mice. PLoS One 9: e110150, 2014.

41. Ning H, Zhang W, Kang J, Ding T, Liang X, Lu Y, Guo C, Sun W, Wang H, Bai Y and Shen L: Subunit vaccine ESAT-6:c-di-AMP delivered by intranasal route elicits immune responses and protects against mycobacterium tuberculosis infection. Front Cell Infect Microbiol 11: 647220, 2021.

42. Schroder K, Hertzog PJ, Ravasi $T$ and Hume DA: Interferon-gamma: An overview of signals, mechanisms and functions. J Leukoc Biol 75: 163-189, 2004.

43. Levy Y and Brouet JC: Interleukin-10 prevents spontaneous death of germinal center B cells by induction of the bcl-2 protein. J Clin Invest 93: 424-428, 1994.

44. Rousset F, Garcia E, Defrance T, Péronne C, Vezzio N, Hsu DH, Kastelein R, Moore KW and Banchereau J: Interleukin 10 is a potent growth and differentiation factor for activated human B lymphocytes. Proc Natl Acad Sci USA 89: 1890-1893, 1992.

45. Rousset F, Peyrol S, Garcia E, Vezzio N, Andujar M, Grimaud JA and Banchereau J: Long-term cultured CD40-activated B lymphocytes differentiate into plasma cells in response to IL-10 but not IL-4. Int Immunol 7: 1243-1253, 1995. 
46. Wang X, Wong K, Ouyang W and Rutz S: Targeting IL-10 family cytokines for the treatment of human diseases. Cold Spring Harb Perspect Biol 11: a028548, 2019.

47. Mazer M, Unsinger J, Drewry A, Walton A, Osborne D, Blood T, Hotchkiss R and Remy KE: IL-10 has differential effects on the innate and adaptive immune systems of septic patients. J Immunol 203: 2088-2099, 2019.

48. Davinelli S, Melvang HM, Andersen LP, Scapagnini G and Nielsen ME: Astaxanthin from shrimp cephalothorax stimulates the immune response by enhancing IFN- $\gamma$, IL-10, and IL-2 secretion in splenocytes of helicobacter pylori-infected mice. Mar Drugs 17: 382, 2019

49. Lin HY, Juan SH, Shen SC, Hsu FL and Chen YC: Inhibition of lipopolysaccharide-induced nitric oxide production by flavonoids in RAW264.7 macrophages involves heme oxygenase-1. Biochem Pharmacol 66: 1821-32, 2003.
50. Means TK, Lien E, Yoshimura A, Wang S, Golenbock DT and Fenton MJ: The CD14 ligands lipoarabinomannan and lipopolysaccharide differ in their requirement for toll-like receptors. J Immunol 163: 6748-6755, 1999.

51. Pi J, Li T, Liu J, Su X, Wang R, Yang F, Bai H, Jin H and Cai J: Detection of lipopolysaccharide induced inflammatory responses in RAW264.7 macrophages using atomic force microscope. Micron 65: 1-9, 2014.

52. Yin M, Zhang Y and Li H: Advances in research on immunoregulation of macrophages by plant polysaccharides. Front Immunol 10: 145, 2019. 